\title{
La Fuga
}

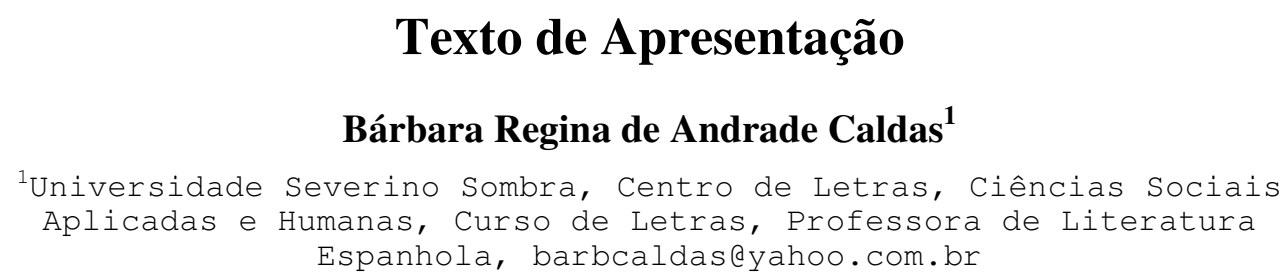

Autor de inúmeros contos e poesias, Carlos Cruz também é o ganhador do I Concurso de Literatura do Centro de Conspiração Popular Gargarullo, de Miguel Pereira / RJ, com o conto O Processo ou A Multiplicação das Mães, escrito em homenagem a sua falecida avó materna. Além disso, o autor também tem uma pequena participação na publicação de Retalhos, uma antologia de contos publicada pela Editora Andross.

Amante de escritores hispânicos, como Gabriel García Márquez entre outros, Carlos Cruz é aluno do $5^{\circ}$ período do curso de letras, habilitação em português-espanhol, na Universidade Severino Sombra. Quando estava apenas no $2^{\circ}$ período da graduação, Carlos escreveu o poema de caráter amoroso La Fuga, o que demonstra o seu comprometimento não só com o universo da leitura e da escrita, como também com a cultura hispânica em si, já que dito poema está escrito em espanhol. 


\section{La Fuga}

\section{Carlos André da Cruz Silva ${ }^{1}$}

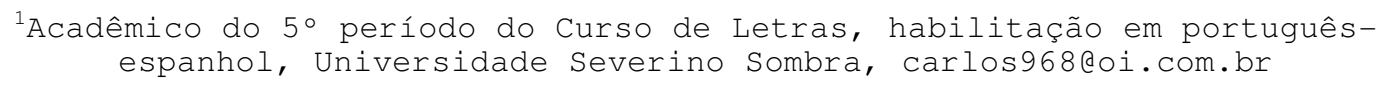

Recorrí las playas de arenas ardientes

quemando las plantas de mis doloridos pies

Enfrenté las olas del mar bravío

mi cuerpo azotado por el látigo hecho de agua

Subí a la cumbre de la montaña más alta

las heridas de mis manos bañaron las piedras

coloreándolas con el rojo de mi sangre

Me perdí en la selva verde y húmeda

llena de musgo y sonidos amedrentadores

Al fin, agotado por la caminata escabrosa

Me senté al suelo y sonreí

Intenté dejarte a lo lejos

escapar de tus presas de mujer felina

pero no pude resistir a tus encantos y encantamientos

ni al amor que devora mi corazón

que late, desesperado, siempre cuando mis ojos miran

tu cuerpo

Carlos Cruz - 08/10/2008 